\title{
PRODUKSI DAN DISTRIBUSI SASTRA KANON: STUDI KASUS PENERBITAN BUKU UMAR KAYAM
}

\author{
PRODUCTION AND DISTRIBUTION CANON LITERATURE: \\ CASE STUDY UMAR KAYAM'S BOOK PUBLISHING
}

\author{
Mawaidi; Suroso \\ Universitas Negeri Yogyakarta \\ Jalan Colombo No.1, Karang Malang, Caturtunggal, Depok, Sleman, Yogyakarta, Indonesia \\ mawaidimasgiarto@gmail.com; suroso@uny.ac.id
}

(Naskah diterima tanggal 30 Mei 2021, direvisi terakhir tanggal 8 November 2021, dan disetujui tanggal 29 November 2021)

DOI: https:/ /doi.org/10.26499/wdprw.v49i2.841

\begin{abstract}
The birth of the publisher indie as an agent of the literature books canon cannot be released from the publishing history of the Dutch Indian era. The spirit of the indie publisher is resisting the dominance of the readership and the literature pop market. One of the publishers in indie was Pojok Cerpen with Umar Kayam's book choice. This method of research used interview, reading, and writing techniques. Interview techniques are conducted to challenge information from publishers, in this case seeking data related to canon literature and literary canon distribution patterns. The data was reviewed through the literary sociology of Pierre Bourdieu. The results are as follows. First, the canonicity of Umar Kayam's personal figure and also the canonicity of Umar Kayam's. The aspect of Umar Kayam's personal canonicity included his culture, education, and family influence. The canonicity aspect of Umar Kayam includes the influence of bestowed and the republishing of Seribu Kunang-kunang di Manhattan book at different publishers. Second, distribution aspects on reseller networks with $60 \%$ reseller power and the remaining conventional bookstores and festi-vals.
\end{abstract}

Keywords: canon literature; indie publisher; umar kayam

\begin{abstract}
Abstrak
Lahirnya penerbit indie sebagai agen produksi buku sastra kanon tidak bisa dilepaskan dari sejarah penerbitan dari era kolonial Hindia Belanda. Semangat penerbit indie melakukan perlawanan terhadap dominasi selera pembaca dan pasar sastra pop. Salah satu penerbit indie tersebut adalah Pojok Cerpen dengan pilihan buku karya Umar Kayam yang ditinjau melalui sosiologi sastra Pierre Bourdieu. Metode pengumpulan data menggunakan teknik wawancara, membaca, dan mencatat. Teknik wawancara dilakukan untuk mengulik informasi dari penerbit, dalam hal ini berupaya mendapatkan data terkait pertimbangan reproduksi karya sastra kanon dan pola distribusi sastra kanon. Hasil penelitian sebagai berikut. Pertama, aspek kanonitas sosok personal Umar Kayam dan aspek kanonitas karya Umar Kayam. Aspek kanonitas personal Umar Kayam meliputi kiprahnya di bidang kebudayaan, pendidikan, dan pengaruh keluarga. Aspek kanonitas karya Umar Kayam meliputi pengaruh penganugerahan dan penerbitan ulang buku Seribu Kunang-Kunang di Manhattan di penerbit yang berbeda-beda. Kedua, aspek distribusi melalui jejaring reseller dengan daya serap $60 \%$ dan sisanya toko buku konvensional dan festival-festival.
\end{abstract}

Kata-kata Kunci: sastra kanon; penerbit indie; umar kayam 


\section{Pendahuluan}

Penerbitan Indonesia telah membentangkan sejarahnya bahwa kekuasaan pemerintah kolonial Belanda begitu dominan dalam menentukan arah perjalanan kesusastraan Indonesia. Atas pengendalian tersebut sejarah niscaya selalu berpihak pada penguasa. Hal ini juga terjadi dalam sejarah pers Indonesia. Jika tidak pantas dianggap sebagai pembohongan, usaha memproduksi informasi yang dilakukan pemerintah kolonial telah melakukan suatu penyele-wengan faktafakta yang harusnya dikemu-kakan ke masyarakat.

Pada masa penjajahannya sejak abad ke16, pemerintah kolonial baru memikirkan kemajuan rakyat jajahannya pada pertengahan abad ke-19. Empat abad merupakan sebuah waktu yang lama. Pada 1948 pemerintah kolo-nial baru merealisasikan bentuk pemikiran-nya berupa pendirian sekolah bagi pribumi di Jawa sebesar 25,000 gulden setiap tahun yang dianggarkan dari dana pembangunan. Kebijakan pendirian lembaga sekolah ini juga atas kepercayaan Raja Belanda kepada pemerintah kolonial saat itu (Suwondo, 1997: 1).

Karya sastra yang terbit di masa itu dido-minasi oleh bahasa Melayu Rendah (Melayu Tionghoa dan Betawi) bukan dari bahasa Melayu Tinggi (Melayu Riau). Melihat perkembangannya yang siginifikan, pemerintah kolonial Belanda kebakaran jenggot dan membuat rencana-rencana yang sifatnya struktural. Kekhawatiran pada pemerintah kolonial salah satunya menganggap karya sastra yang terbit pada masa itu bertendensi pada tema-tema sex and violence. Antisipasi yang dilakukan pemerintah kolonial membentuk Comissie voor de lnlandsche School en Volkslectuur (Komisi untuk Sekolah Pribumi dan Bacaan Rakyat) pada 14 September 1908. Rupanya pembentukan komisi ini disesuaikan dengan salah satu program politik etis (etische politiek) yang di-canangkan sejak 1901 oleh pemerintah kolonial. Karya-karya yang diterbitkan adalah cerita rakyat, cerita wayang, hikayat lama, cerita-cerita teladan, dan sejenisnya. Tujuan diterbitkannya karyakarya itu agar masyarakat tidak memperoleh bacaan (modern) yang dianggap berbahaya dan mereka dapat terhindar dari "bacaan liar" (Suwondo, 1997:3).

Bacaan liar-meliputi di dalamnya produk karya sastra-merupakan label untuk tulisan-tulisan kaum pergerakan. Label ini pertama kali diutarakan Rinkes pada 1914 dalam "De Imhemse Pers" yang berangkat dari kekhawatiran pemerintah kolonial terhadap terbitan-terbitan seperti surat kabar, jurnal, novel, dan bentuk bacaan-bacaan lainnya. Pernyataan ringkas ini merupakan pokok dari perdebatannya dengan Mas Marco Kartodikromo pada tahun itu tentang hasil kerja Mindre Welvaart Commissie-oleh Mas Marco dianggap sebagai usaha mempertahankan mitos politik etis (Razif, 2005: 37-38); (Sulton, 2015: 228).

Kendati pemerintah kolonial telah mengeluarkan kebijakan tertentu dalam penerbitan bacaan (sastra), para penerbit swasta masih tetap aktif menerbitkan buku-buku berbahasa Melayu Rendah bagi masyarakatnya. Melalui penerbit swasta itu pengarang merasa lebih bebas berekspresi dan lebih leluasa mengeluarkan gagasannya sesuai dengan selera pembaca.

Gejolak produksi karya sastra di tahuntahun setelah kepemimpinan Soeharto usai dari muka bumi, produksi karya sastra meng-gejala di koran-koran sebagai euforia setelah sekian puluh tahun gagasan-gagasan dibung-kam. Terbit majalah, situs web, stensilan, dan penerbit buku indie sebagai respons atas dominasi penerbit mayor berkarakter raksasa 1 .

Upaya telaah historisitas atas kemunculan penerbit di Indonesia di atas diperlukan 
adanya relevansi atas kemunculan penerbitpenerbit sesudahnya dengan semangat yang sama yaitu penerbitan buku-buku sastra. Historisitas ini berupaya menengok kembali masa modern awal yang ditandai oleh persentuhan masyarakat Indonesia dengan kebudayaan Eropa dan usaha pener-bitan dengan teknologi cetak tergolong unsur budaya baru pada waktu itu (Kasijanto, 2008: 286).

Kelahiran sastra Indonesia dan produksi penerbitannya, bagai dua sisi mata uang yang tidak dapat dipisahkan. Di mana ada karya sastra muncul, di situ proses penerbitannya bekerja. Kemunculan penerbitannnya ditan-dai oleh sejumlah hal dari masa ke masa, sekaligus mengalami perubahan didukung perkembangan zaman. Dari yang munculnya dilakukan secara profesional, seperti penerbitan era pemerintah Hindia Belanda hingga masa penjajahan Jepang, hingga munculnya penerbitan secara amatiran. Keduanya memiliki sinergi oposisi yang kuat, tajam, represif, sekaligus resistan. Misalnya, penerbitan milik penguasa kolonial versus penerbitan milik pribumi, penerbitan milik penguasa Hindia Belanda versus penerbitan milik kolonial Jepang, penerbitan milik pribumi versus milik pribumi.

Dalam konteks sastra, yang terakhir dise-but ini kemunculannya mengemuka pascake-merdekaan. Misalnya, Lembaga Kebudayaan Rakyat versus Manifes Kebudayaan, Majalah Horison dengan propaganda antikomunis-menya ${ }^{2}$ versus sastra koran yang tidak tendensif, dan sastra populer versus sastra kanon.

Dalam hal ini ada semangat ideologis pada penerbit Pustaka Jaya pada 1966 yang menerbitkan pertama kali Seribu KunangKunang di Manhattan karya Umar Kayam. Sementara itu oleh Pojok Cerpen, selaku penerbit indie, diproduksi ulang pada 2018. Sejak 2015, Pojok Cerpen telah menaungi lini penerbit Oak dan toko buku Pocer. Dalam perja-lanannya, Pojok Cerpen berdiri secara in- dependen sebagai penerbit dengan bukubuku sastra kanon dalam dan luar negeri, namun tidak terbatas juga penerbitan bukubuku sastra kalangan sastrawan muda dengan tetap mempertimbangkan kualitas.

Penerbit indie, sejak kemunculannya era 2000-an menawarkan dua pokok dalam meng-hadapi mekanisme penerbitan. Pertama, self publishing yaitu penulis menerbitkan secara mandiri. Penulis menanggung biaya produksi yang diserahkan kepada penyedia jasa-dalam hal ini penerbit-untuk mengeksekusi karyanya. Model penerbitan seperti ini meru-pakan respons para penulis yang karyanya ditolak penerbit mayor dengan berbagai alasan seperti standar kualitas tulisan atau tulisan yang tidak memiliki pasar. Namun, tidak semua tulisan yang ditolak penerbit mayor memiliki reputasi buruk secara kualitas maupun distribusi. Atau, penulis berkebutuhan secara administrasi guna diserahkan kepada sebuah lembaga yang membiayai penelitiannya.

Bagian ini merupakan pokok yang kedua dalam manajemen indie. Dalam perkemba-ngannya penerbitan indie juga menjaring nas-kah secara prosedural dengan tidak melibat-kan penulis dalam pembiayaan. Model mana-jemen seperti ini juga merespons atas ketidak-adilan pasar yang mengharuskan penerbit menyerahkan minimal 3.000 eksemplar ${ }^{3}$ ke agen distributor. Pengelolaan oplah secara indie ini mengambil kemudi distribusi melalui jejaring daring (online shop) dengan melakukan pembatasan oplah dari 10 eksemplar hingga 1.000 eksemplar.

"Indie" yang disematkan pada penerbit berskala kecil ini juga merujuk terhadap independensi redaksi dalam menentukan naskah. ${ }^{4}$ Upaya independensi tersebut tampak pada ketidaktundukannya redaksi dalam mengek-sekusi selera pasar atau pada topik-topik how to. Pada 2015-an, penerbit indie yang baru tumbuh berkembang menerbitkan ulang karya-karya kanon lama da- 
lam sastra di tengah deras arusnya pasar bu$\mathrm{ku}$ sastra populer (teen literature), novel islami, dan novel perja-lanan inspiratif yang memberikan efek panjang bagi pembaca sastra dalam waktu hampir satu dekade. Untuk menguji seberapa berpenga-ruhnya karya berlabel tersebut, diperlukan hadirnya kritik terhadap beberapa penerbit yang menyemarakkan terbitannya pada tahun 2000-an (Liliani, 2011: 3). Bahkan, ada sebuah penerbit yang berani melabeli novel anak dengan label "islami". Pelabelan tersebut memunculkan berbagai pertanyaan, termasuk tolok ukur "islami" dalam karya dan kecenderungan pelabelan yang hanya berujung pada strategi pemasaran.

Bangkitnya penerbit indie dengan terbitan sastra kanonnya dimulai dari karya sastra terjemahan, disusul dengan karya sastra kanon Indonesia yang dianggap berpengaruh. Sastra kanon adalah sastra yang memuat suatu ga-gasan, wacana hasil pemikiran, atau perenung-an sastrawan yang disajikan kepada pembaca secara estetik (Trianton, 2019: 7). Dengan mempertimbangkan mutu kualitasnya, sastra kanon tidak hanya memberikan kesan hiburan melalui keindahan bahasa dan cerita, tetapi memberikan sentuhan nilai-nilai humanisme, yang justru dalam semangat sastra populer kecenderungannya pada semangat hiburan dan memilih tema-tema cerita picisan.

Sastra kanon Indonesia dicontohkan dengan karya-karya angkatan Balai Pustaka, Pujangga Baru, dan Angkatan 45. Walaupun demikian - selain juga setiap lembaga sastra memiliki legitimasi atas sastra kanon sendiri-kanonitas sastra bukanlah suatu capaian statis, mandek, dan selesai. Akan tetapi kanonitas sastra terus berproses, tumbuh, dan berkem-bang seiring dengan perkembangan zaman. Suatu karya yang mulanya termasuk dalam kanon sastra dapat saja kemudian tidak diakui lagi; demikian pula sebaliknya. Perubahan tersebut disebabkan oleh adanya perkembangan ilmu dan wacana yang berkembang di masyarakat (Sumarno, 2015: 22).

Sebagai penerbit indie yang baru saja merangkak, sastra kanon dibutuhkan untuk mendongkrak reputasi penerbit, selain pentingnya sastra kanon sebagai parameter kesusastraan. Berbeda dengan penerbit baru yang memiliki semangat mayor, sejak awal memilih sastra populer yang memiliki daya serap cepat di pasaran.

Berbekal semangat ideologis, penerbit indie mencari naskah lama yang diterbitkan ulang, baik sastra terjemahan maupun sastra asli berbahasa Indonesia. Semangat ideologis tersebut sebenarnya mengacu pada selera pri-badi yang dianggap bermutu dan pasar sudah lesu meresponsnya. Dalam kasus ini karya Umar Kayam yang diterbitkan oleh Pojok Cerpen, sebuah penerbit yang berbasis di Yogyakarta, setidaknya tidak serta merta mengabaikan pertimbangan-pertimbangan modalitas yang dimiliki Umar Kayam.

Modal setidak-tidaknya merupakan barang langka yang harus ada pada diri agen (para pelaku) di dalam sebuah arena. Secara garis besar modal terbagi dalam empat jenis, yakni ekonomi, budaya, sosial, dan simbolik. Modal harus ada dalam suatu arena agar dapat memiliki arti. Modal juga diposisikan sebagai basis dominasi suatu agen. Beragam jenis modal dapat ditukar dengan jenis-jenis modal lainnya-yang artinya modal bersifat adaptif. Adapun bagaimana ragam modal itu bekerja di dalam pertaruhan suatu arena bergantung pada strategi yang digunakan oleh agen (Salam dan Anwar, 2015: 28).

Umar Kayam yang diposisikan sebagai para pelaku (agen) di dalam formasi sosial sastra merupakan penulis pilihan Pojok Cerpen dengan mempertimbangkan keempat jenis modal di atas, yaitu setidak-tidaknya atas pertimbangan kanonitas diri penulis dan kanonitas karyanya.

Baik Umar Kayam sebagai sosok penulis maupun karya-karya yang dihasilkannya 
adalah 'karya seni' yang dapat ada sebagai objek simbolik hanya jika mereka diketahui dan diakui, yaitu, dilembagakan secara sosial dan diterima oleh pembaca (Bourdieu, 1993: 37). Adanya sebuah lembaga yang diberi nama Yayasan Seribu Kunang-Kunang misalnya, tidak bisa dilepaskan dari pengaruh modalitas tersebut. Seperangkat agen yang upaya gabungannya menghasil-kan konsumen sehingga mampu mengetahui dan mengenali 'karya seni' tersebut tidak bisa begitu saja dicerai-beraikan.

Dengan demikian dalam konteks arena sastra, agen mendapatkan posisi sosial arena sastra jika berada pada jalur hierarki ganda. Pertama, heteronom yaitu keberhasilan yang diukur dengan pendistribusian buku, jumlah penjualan tiket jika konteksnya pertunjukan teater, atau penghargaan, nominasi, dan lainlain sehingga akan mendatangkan nilai ekonomi. Kedua, jalur otonom yaitu pentahbisan atau pengakuan dari ahli sastra, misalnya dengan cara memberikan pengantar dalam bukunya dan hal ini lazimnya berbanding terbalik dengan keuntungan nilai ekonomi (Bourdieu, 1993: 38-39).

Melalui pendekatan sosiologi sastra Pierre Bourdieu, lebih khusus mengenal konsep mo-dalnya, penelitian ini berusaha mengajukan sebuah pertanyaan mendasar. Pertama, atas pertimbangan kanonitas apa karya Umar Kayam diterbitkan ulang? Kedua, bagaimana pola distribusi buku Umar Kayam yang me-makai strategi pentahbisan?

Pertanyaan-pertanyaan di atas bagian dari usaha melengkapi penelitian sebelumnya. Pertama, artikel berjudul Modal-Modal Majalah Pagagan: Tinjauan Sosiologi Pierre Bourdieu dengan temuannya bahwa modal ekonomi, simbolik, dan kultural mendorong timbulnya strategi-strategi redaksi yang menyebabkan Pagagan dapat terbit hingga tahun 2014. Dari ketiga modal tersebut, modal terkuat pendu-kung Pagagan adalah modal kultural (Zamzuri 2014: 165-176).
Kedua, artikel berjudul Kekuasaan dan Kepentingan Internal Lembaga: Kajian Arena Produksi Kultural Bourdieu (Studi Kasus Penerbit Bandar Publishing di Kota Banda Aceh) dengan temuanya bahwa kekuasaan sebuah arena ter-gantung agen di dalamnya dalam menentukan special characterictic untuk membedakannya dengan arena-arena lain. Penerbit tidak dapat mengubah penetapan tema yang sudah diber-lakukan Bandar sejak berdiri. Penulis dapat mengirimkan naskah dengan gagasan utama tentang Aceh, mereka tunduk dan patuh ter-hadap ketentuan yang berlaku, dalam artian penulis tunduk di bawah kekuasaan penerbit. Bandar Publishing sebagai penerbit independen yang diinisiasikan oleh beberapa mahasiswa dan dosen, memiliki keinginan untuk menjaga sejarah-sejarah dan kultur-kultur Aceh dengan mencetak bukubuku bertemakan Aceh (Linda, 2019: 157177).

\section{Metode}

Objek penelitian ini adalah penerbit Pojok Cerpen yang ada di Yogyakarta. Pojok Cerpen dipilih karena konsistensinya memproduksi buku-buku karya sastra pengarang Indonesia. Adapun sastra kanon yang diterbitkan oleh Pojok Cerpen ialah karya Umar Kayam ber-judul Seribu KunangKunang di Manhattan (2018).

Data penelitian ini dikumpulkan melalui teknik wawancara, lanjut membaca dokumen dan mencatatnya sebagai upaya telaah historis dan komparasi. Teknik wawancara dilakukan untuk mendapatkan data terkini dari penerbit. Wawancara utamanya diterapkan untuk mempersiapkan pengumpulan data dan mengembangkan perangkat pengumpulan data. Fungsi dari konsep ini memberi pengetahuan tentang lapangan penelitian yang dibahas, merekam dan menganalisis perspektif sub-jektif para informan, atau mengumpulkan data yang berhubungan dengan biografi (Hopf, 2004: 
203). Pada konteks ini dilakukan upaya menggali data yang berkaitan dengan pertimbangan reproduksi karya sastra kanon dan pola distribusinya dengan memakai konsep pentahbisan ahli atau tokoh. Teknik membaca dan mencatat dilakukan untuk membaca sejumlah tulisan baik berupa artikel, berita, atau jurnal penelitian yang menyinggung fenomena sosial dan kultural yang memungkinkan menjadi latar belakang penerbitan sastra kanon dan distribusinya. Data yang terkumpul kemudian dianalisis melalui teknik deskriptif kualitatif. Data-data yang diperoleh kemudian dikelompokkan berdasarkan permasalahan, disusul analisis secara deskriptif kualitatif. Terakhir peneliti melakukan inferensi dengan memperhatikan aspek permasalahan dan temuan data di lapangan.

\section{Hasil dan Pembahasan}

\subsection{Hasil}

Temuan dalam penelitian ini ialah berupa aspek pertimbangan kanonitas penulis, kanonitas karya, dan pola distribusi yang dilakukan oleh penerbit terhadap Seribu Kunang-Kunang di Manhattan karya Umar Kayam.

Kanonitas penulis mempertimbangkan aspek keluarga, sosiologis, akademik, dan karier. Kanonitas karya dapat dilacak melalui riwayat produksi karya dan penghargaan atas karya Umar Kayam. Terakhir pada pola distribusi yaitu menggunakan penulis muda yang berpengaruh untuk memberikan testimoni, serta melakukan jejaring distribusi seperti mengadakan peluncuran, ikut serta dalam berbagai bazar atau festival, dan terakhir distribusi ke jejaring toko daring dan luring. Berikut tabel hasil penelitian yang menunjukkan beberapa aspek sastra kanon.
Tabel 1

Aspek pertimbangan kanonitas sastra Umar Kayam

\begin{tabular}{|c|c|c|c|}
\hline No & $\begin{array}{c}\text { Kanonitas } \\
\text { Penulis }\end{array}$ & $\begin{array}{c}\text { Kanonitas } \\
\text { Buku }\end{array}$ & $\begin{array}{c}\text { Pola Distri- } \\
\text { busi }\end{array}$ \\
\hline 1 & Keluarga & $\begin{array}{c}\text { Riwayat } \\
\text { Produksi } \\
\text { Karya }\end{array}$ & $\begin{array}{l}\text { Testimoni } \\
\text { Tokoh }\end{array}$ \\
\hline 2 & Sosiologis & $\begin{array}{c}\text { Riwayat } \\
\text { Penghar- } \\
\text { gaan } \\
\text { Karya }\end{array}$ & $\begin{array}{c}\text { Toko Daring } \\
\text { dan Luring }\end{array}$ \\
\hline 3 & Akademik & - & Peluncuran \\
\hline 4 & Karier & - & $\begin{array}{c}\text { Bazar atau } \\
\text { Festival }\end{array}$ \\
\hline
\end{tabular}

\subsection{Pembahasan}

\subsubsection{Kanonitas Penulis}

Kanonitas sastra yang menjadi pertimbangan penerbit Pojok Cerpen tidak hanya sekadar berfokus pada nama besar, tetapi pada pertimbangan empiris dengan melacak profil Umar Kayam. Pelacakan ini juga nantinya yang akan menjadi pijakan strategi distribusi (marketing strategy). Penerbitan buku Umar Kayam merupakan impian sebuah dapur redaksi penerbitan. Dilihat dari aspek biografisnya, Umar Kayam sosok pribadi yang tidak hanya sekadar terkenal sebagai sastrawan, tetapi juga aktor, budayawan, dan sosio-log. Umar Kayam juga memiliki daftar sepak terjang karier yang pernah dijabatnya, dalam aspek ini tentu memiliki pengaruh yang kuat bagi kualitas karya dan juga pembaca.

Aspek pertimbangan kanonitas penulis di antaranya aspek keluarga, sosiologis, akademik, dan karier. Pertama, aspek keluarga Umar Kayam berasal dari keluarga priyayi yang bergelar raden mas. Kedua, aspek sosiologis meliputi sebutan khas untuk Umar Kayam yaitu aktor, budayawan, sastrawan, sosiolog. Ketiga, aspek akademik yaitu pendidikan yang pernah ditempuh Umar kayam di antaranya di Fakultas Sastra, 
Pedagogik, dan Filsafat Universitas Gadjah Mada pada 1955, meraih gelar Master of Art Universitas New York, AS pada 1963, dan meraih gelar Ph.D. bidang sosiologi Universitas Cornell, AS pada 1965. Keempat, aspek karier yaitu tempat Umar Kayam berkiprah di antaranya pernah menjadi dosen Sekolah Tinggi Filsafat Driyakara, Jakarta, pernah menjadi dosen Universitas Indonesia, direktur Jenderal Radio, Televisi, dan Film Departemen Penerangan RI (196669), Ketua Dewan Kesenian Jakarta (1969-72), Senior fellow pada East-West Center, Hawaii, AS (1973), Direktur Pusat Latihan Ilmu-Ilmu Sosial Universitas Hasanuddin, Ujungpandang (1975-76), Direktur Pusat Penelitian Kebudayaan Universitas Gadjah Mada (1977), Ketua Dewan Film Nasional (1978-79), Ketua Lembaga Pendidikan Kesenian Jakarta (1981), Guru Besar Fakultas Sastra, Universitas Gadjah Mada, Yogyakarta (1988pensiun), anggota penyantun majalah Horison (mengundurkan diri sejak 1 September 1993), dan anggota Akademi Jakarta (1988-seumur hidup).

Semua penulis akan menghasilkan sastra kanon apabila karya yang dihasilkan memuat gagasan yang mengandung nilainilai filosofis sebuah sejarah atau nilai-nilai suatu kebudayaan tertentu. Muatan gagasan ini dalam sebuah karya sastra kanon perlu mempertimbangkan juga aspek filsafat, psikologi, dan moral lainnya. Karenanya, sastra yang baik tidak hanya memberikan cerita melalui tokoh dalam suatu alur dan penokohan tanpa menyematkan nilai-nilai tersebut yang tumbuh dari hasil pikiran pengarang (Trianton, 2019: 3). Di hampir semua karya sastra Umar Kayam, tidak sedikit yang tidak menyinggung nilai-nilai filosofis kemanusian dan budayanya. Nilainilai filosofis tersebut mengemuka dalam dua novelnya Para Priyayi dan Jalan Menikung. Dalam kumpulan cerpen Seribu KunangKunang di Manhattan secara satire be-rangkat dari proses penulisan yang dilatar-belakangi oleh perampasan tas yang dilihat langsung oleh Umar Kayam, ${ }^{5}$ sebuah kejadian berlatar Manhattan, New York, Amerika. Secara keseluruhan cerpen-cerpen yang ada di buku ini mengisahkan citra masyarakat mo-dern tempat penulis menyelesaikan studi master dan doktoralnya.

Penerbitan buku Umar Kayam oleh Pojok Cerpen yang berjudul cerpen Seribu Kunang-Kunang di Manhattan memiliki relevansi dengan pernyataan tentang buku yang bernapas panjang dan buku yang bernapas pendek (Anwar, 2015: 82). Posisi Pojok Cerpen sebagai penerbit indie sudah berada di jalur yang aman. Penerbit indie meminimalkan oplah yaitu di kisaran 101.000 eksemplar, berbeda dengan yang dilakukan penerbit mayor yaitu 2.500 hingga 3.000 untuk cetakan pertama. Karya Umar Kayam yang diterbit-kan Pojok Cerpen pada awalnya dicetak sejumlah 300 eksemplar. ${ }^{6}$ Dengan pola produksi demikian, Pojok Cerpen tidak ingin ada bad stock di gudang. Eka Wijaya menambahkan bahwa di kalangan penerbit indie stok bukan tujuan utama, tetapi jumlah judul yang paling diprioritaskan. Penim-bunan stok bisa terjadi di penerbit berskala mayor dengan pertimbangan distribusi berskala besar pula. Tugas penerbit indie mengurangi stok dan mengalokasikan anggaran untuk judul-judul yang lain.

Secara tematik di riwayat pasar distribusi, buku Seribu Kunang-Kunang di Manhattan tidak selaku buku sastra populer. Jenis buku sastra popular memilih berada pada jalur buku bernapas pendek-dalam arti laku keras-dalam jangka waktu yang singkat. Sementara buku Umar Kayam selain memang berada pada jalurnya yang indie, didukung dengan pola distribusi yang memakan waktu panjang, yaitu para pembaca yang tersegmen ke dalam mahasiswa sastra dan penyuka sastra. 
Dalam konstelasi sejarah sastra Indonesia, Umar Kayam merupakan sosok yang tidak bisa dilepaskan dari jaring-jaring perkembangan sastra Indonesia modern. Kanonitas personalnya berhubungan erat dengan karya, relasi, dan institusi yang membangunnya. Ada tiga prinsip seorang individu dilegitimasi sebagai agen kultural. Pertama, seorang individu sesuai dengan pengakuan yang diberikan oleh agen kultural yang lain; apakah sebagai kolaborator atau bahkan sebagai pesaing. Kedua, mengacu pada pengakuan yang diberikan oleh elite budaya, otoritas budaya, dan khalayak. Ketiga, ditentukan oleh pilihan dan preferensi populer (Bourdieu, 1993: 50-51).

Dalam peta kesusastraan Indonesia, Umar Kayam dikenal sebagai penulis prosa yang berhasil. Umar Kayam dianggap telah melahir-kan karya sastra yang berkualitas. Selain itu Umar Kayam menulis esai. Dalam kesibukannya sebagai guru besar Universitas Gadjah Mada, Umar Kayam tidak hanya menulis esai sastra, seni (teater dan film), tetapi juga esai kebudayaan. Sebagian esai kebudayaan itu dimuat dalam Seni, Tradisi, Masyarakat (1981) dan Sejumlah Masalah Sastra (1983) oleh Satyagraha Hoerip buku ini dieditorinya. Di bidang film Umar Kayam pernah berperan sebagai aktor dalam film "Karmila" dan "Pengkhianatan G-30-S PKI". Dalam film yang kedua ini Umar Kayam memerankan Bung Karno sebagai Presiden Republik Indonesia (Sugono, 2003: 256).

Pada 2005, terbit buku Umar Kayam Luar Dalam: 30 April 1932-16 Maret 2002 diterbitkan Yayasan Seribu Kunang-Kunang bekerja sama dengan Penerbit Pinus, Yogyakarta (Dewanto, 2005). Buku ini perlu hadir di tengah pembaca dimaksudkan untuk mengeksplorasi bagian-bagian yang belum terungkap dari kedirian sosok budayawan, sastrawan, sosiolog, aktor dari Umar Kayam. Buku ini juga berusaha melihat sosok pribadi Umar Kayam dari ma- sa muda hingga akhir hayatnya. Ada banyak penulis terkemuka yang ikut menulis di buku ini antara lain Nirwan Dewanto, Ashadi Siregar, Faruk, Sapardi Djoko Damono, Ahmadun Yosi Herfanda, Sartono Kartodirdjo, dan lainnya.

Pada 2004 juga terbit buku berjudul Umar Kayam: Karya dan Dunianya diterbitkan Gra-sindo (Rahmanto, 2004). B. Rahmanto merupa-kan salah seorang sastrawan dan dosen senior Universitas Sanata Dharma. Buku ini mengupas proses kreatif Umar Kayam berikut karya-karyanya yang lain seperti Sri Sumarah dan cerita pendek lainnya, Parta Karma, dan Lebaran di Karet, di Karet ... dan dua novelnya Para Priyayi dan Jalan Menikung.

\subsubsection{Kanonitas Karya}

Dilihat dari aspek karya-karyanya, khusus buku Seribu Kunang-Kunang di Manhattan telah banyak cetakan buku tersebut dari penerbit yang berbeda-beda. Penerbitan ulang dari tahun ke tahun ini menandakan adanya respons yang kuat dari pembaca, dari generasi ke generasi. Karya-karya Umar Kayam yang lain seperti novel dan kumpulan esai-esainya juga memiliki pengaruh yang kuat terhadap para pembaca. Aspek pertimbangan kanonitas Seribu Kunang-Kunang di Manhattan meliputi riwayat produksi karya dan riwayat penghargaan karya.

Pertama, riwayat produksi karya di antaranya Cerpen "Seribu Kunang-Kunang di Manhattan" terbit di Majalah Horison No. 04 tahun I, Oktober 1966, diterbitkan pertama kali sebagai buku oleh Pustaka Jaya, Jakarta pada 1972, terbit ulang oleh Yayasan Obor Indonesia, Jakarta bekerja sama dengan Program Pemetaan Bahasa Nusantara dan Ford Foundation pada 1999 khusus cerpen "Seribu Kunang-Kunang di Manhattan" yang diterjemahkan ke dalam 13 bahasa daerah-di samping naskah aslinya-yang terdiri dari 
bahasa Aceh, Batak Toba, Minangkabau, Sunda, Cirebon, Jawa, Madura, Bali, Sasak, Bugis Makassar, Bugis, Toraja, dan Mandar. Kemudian, terbit ulang oleh Grafiti Press, Jakarta pada 2003, dan terakhir terbit ulang oleh Pojok Cerpen, Yogyakarta pada 2018.

Kedua, riwayat penghargaan karya di antaranya cerpen "Seribu Kunang-Kunang di Manhattan" menjadi pemenang hadiah sastra majalah Horison kategori cerita pendek pada 1967, novel Para Priyayi mendapatkan Hadiah Yayasan Buku Utama Departemen Pendidikan dan Kebudayaan pada 1995, dan terakhir atas sejumlah karyanya Umar Kayam memperoleh Hadiah Sastra Asean pada 1987 dari Kerajaan Thailand.

Ruang-ruang sosial dari wilayah yang terdekat (keluarga), wilayah pertemanan dan kultural (sosiologis), hingga wilayah kerjakerja profesional dan komunitas (akademik dan karier) merupakan ladang-ladang yang dibuat oleh Umar Kayam. Menurut Bourdieu, ruang sosial dibagi menjadi bidang-bidang yang berbeda, yang ia sebut sebagai ladang (Schwetter, 2019: 192). Ladang-ladang tersebut adalah kiprah atau keterlibatan Umar Kayam dalam membangun relasi yang terkoneksi dengan unsurunsur yang ditekuninya; sebagai sosiolog, sastrawan, aktor, dan budayawan.

Namun, ladang-ladang yang dibangun oleh Umar Kayam perlu dilihat dari seberapa terhubung dengan hasil karya-karyanya yang merupakan buah dari ladang tersebut. Salah satu karya Umar Kayam yang banyak melibat-kan aspek kultural dan kerja akademiknya terlihat pada karya esainya. Bagaimana de-ngan karya-karya sastra Umar Kayam selain Seribu Kunang-Kunang di Manhattan? Tidak semua penulis sastra kanon menghasilkan karya sastra kanon yang sama dengan karya yang menandai kemahakaryaannya. Umar Kayam merupakan salah pengarang terkemuka yang masuk ke dalam daftar tersebut.
Hal ini mungkin ada relevansinya dengan penilaian Sudibyo bahwa sosok Umar Karyam merupakan pengarang yang tidak produktif. Namun, setiap karya yang lahir dari tangan-nya mampu menunjukkan kelasnya dengan jajaran pengarang sastra Indonesia di zamannya. Sayangnya Sudibyo tidak menyebutkan nama-nama dari jajaran pengarang yang dimaksud (Sudibyo, 2015: 69).

Pada akhirnya karya Umar Kayam yang berjudul Parta Krama (1997) sebagai kumpulan cerpen tidak memiliki nasib yang sama dengan Seribu Kunang-Kunang di Manhattan. Bisa saja tidak relevan jika dibandingkan dengan Sri Sumarah dan Bawuk, atau dwilogi Para Priyayi sebagai karya novel. Dari 1997 hingga sekarang buku Parta Krama tidak pernah mengalami cetak ulang. Di antara karya prosa Umar Kayam yang mengalami cetak ulang berkali-kali dari penerbit yang berbeda hanya Seribu KunangKunang di Manhattan. Buku yang terakhir ini mengalami cetak ulang sebanyak empat kali dan pernah diterjemahkan ke berbagai bahasa asing.

Seribu Kunang-Kunang di Manhattan serta Sri Sumarah dan Bawuk diterbitkan dalam satu edisi bahasa Inggris pada 1980 dan dalam edisi bahasa Belanda pada 1981. Secara terpisah cerpen-cerpen Umar Kayam, terutama yang terkumpul dalam Seribu Kunang-Kunang di Manhattan, itu pun disalin orang ke berbagai bahasa asing, seperti Jepang, Jerman, dan Prancis (Sugono, 2003: 256). Penyalinan ke dalam bahasa asing ini tampaknya dimuat secara parsial di majalahmajalah atau koran-koran yang terbit di luar negeri. Khusus untuk cerpen yang berjudul "Seribu Kunang-Kunang di Manhattan" diterjemahkan ke dalam 12 bahasa Nusantara. Penerjemahan cerpen ini adalah hasil seleksi dari 30-50 peserta yang mengirimkan naskah terjemahan ke panitia yang tersebar di berbagai daerah. Bahkan, 
ada banyak peserta yang belum lahir ketika cerpen Umar Kayam ini pertama kali ditulis (Budiman, 1999).

Dibanding karya novelnya, kumpulan cerpen ini yang paling memikat perhatian pembaca. Pojok Cerpen, yang memang konsentrasi untuk karya-karya cerita pendek, merasa sulit menolak tawaran keluarga Umar Kayam ketika naskah Seribu KunangKunang di Manhattan ditawarkan kepada Eka Wijaya untuk bekerja sama. Pada penerbitan buku pertama tersebut, Pojok Cerpen bagaikan mendapatkan durian runtuh. Sri Sumarah dan Bawuk juga diserahkan kepada Pojok Cerpen oleh keluarga Umar Kayam untuk diterbitkan. Namun, Pojok Cerpen tidak langsung terlena terhadap naskah tersebut. Eka Wijaya beralasan bahwa Pojok Cerpen menahan terlebih dahulu.

Dalam kerja sama antara keluarga Umar Kayam dengan Pojok Cerpen terdapat sebuah hambatan berupa ekspektasi yang cukup tinggi yang disodorkan oleh keluarga Umar Kayam. Terutama dalam hal promosi, Pojok Cerpen sebagai penerbit kecil khawatir jika dirasa sudah berada pada titik maksimal manajemen distribusi penerbit tetapi di fakta lain mengecewakan pemilik naskah. Hingga sekarang, naskah Sri Sumarah dan Bawuk belum terbit di Pojok Cerpen.

Ada dua asumsi untuk mendedah rantai kerja sama antara Pojok Cerpen dan keluarga Umar Kayam yang hampir terbengkalai. Pertama, Pojok Cerpen secara sadar belum dapat memaksimalkan pendistribusian yang berujung pada minimnya sumber daya manusia di internal Pojok Cerpen. Kedua, Seribu Kunang-Kunang di Manhattan belum diserap secara maksimal oleh pasar. Pemampatan distribusi ini kuat dugaan adalah belum kembalinya modal produksi cetakan pertama dan menjadi faktor pesimisnya menangani naskah Sri Sumarah dan Bawuk.

Dalam manajemen penerbit indie yang lain, Cantrik Pustaka misalnya, penerbit yang minat pada karya-karya filsafat dan kebudayaan mendapatkan kepercayaan menerbitkan seluruh karya Yasraf Amir Piliang, baik yang sudah terbit maupun karya terbarunya. Dalam waktu tiga tahun, naskah tebal Yasraf Amir Piliang sudah terbit sekitar tujuh judul. Sebuah capaian yang maksimal dalam manajemen indie. Respons pembaca terhadap karya pemikir kebudayaan itu menjadi oase setelah sekitar satu dasawarsa Yasraf Amir Piliang nyaris lenyap dari peradaban. Dengan demikian, respons pasar yang besar juga selaras dengan animo pembeli buku-buku Yasraf Amir Piliang.

Sebagai pembanding meskipun berada di luar konteks buku sastra, dalam perspektif bisnis, seharusnya karya-karya Umar Kayam masuk ke dalam daftar karya laku keras untuk semua karyanya. Mengingat hal tersebut, pentingnya produksi simbol pada sebuah produk untuk menajamkan interpretasi pembaca. Dengan demikian, mengacu pada konsep arena dan modal yang digagas Bourdieu, maka penerbit jangka panjang adalah mereka yang mengerti dan paham aturan main dalam arena sastra, sehingga strategi dalam menge-mas produknya pun tidak dengan cara-cara biasa, melainkan dengan sejumlah simbol sebab arena sastra adalah tempat pertaruhan modal simbolik para “pemainnya" (Anwar, 2015: 82).

Dalam pandangan yang lain, Murti misalnya mengatakan bahwa gagasan Goldmann yang menekankan karya sastra besar bisa muncul hanya ketika terjadi sebuah "momentum krisis" karena memung-kinkan bangkitnya kesadaran pada diri individual, yang juga membentuk kesadaran koheren dalam memunculkan karya-karya besar (Murti, 2016: 278); (Goldmann, 1980: 87). Pandangan ini kemudian dapat membuka jalan tengah bahwa terbentuknya sastra kanon tidak melulu karena jumlah produksi, tetapi kemunculannya bertepatan dengan 
momentum sosial, politik, dan budaya dalam menemukan relevansinya.

Tidak bisa dimungkiri jika keberadaan sastra kanon pada dasarnya mucul secara politis. Dalam sejarahnya kritikus sastra di luar Indonesia meyakini-seperti kanonisasi pada Bibel - bahwa di balik pretensi "objektivitas" penilaian mutu karya terdapat sebuah agenda politik terselubung, yaitu eksklusi atas banyak kelompok dari representasi dalam kanon sastra. Contoh yang paling sering mengemuka adalah fakta lebih sedikitnya jumlah sastrawan (jenis kelamin) pe-rempuan dalam kanon sastra (Situmorang, 2007).

\subsubsection{Pola Distribusi}

Pola distribusi yang dilakukan Pojok Cerpen mencakup berbagai strategi. Sebagaimana sebuah produk industri, Pojok Cerpen menyertakan testimoni dari sastrawan berpengaruh untuk menyertai buku. Setelah buku terbit, Seribu Kunang-Kunang di Manhattan diluncurkan di sebuah acara berskala nasional. Strategi promosi yang lain di antaranya menyasar generasi milenial sebagai pengagum sastra populer yaitu melalui jejaring daring, toko buku, dan festival atau bazar.

Kekhawatiran Pojok Cerpen terhadap promosi yang kurang maksimal yaitu pada terbuka lebarnya jejaring yang dibuka keluarga Umar Kayam dengan menunjuk komunitas-komunitas yang memakai bendera Umar Kayam, misalnya Yayasan Umar Kayam (YUK), Yayasan Seribu KunangKunang dan lainnya. YUK ini lembaga yang mengembangkan gagasan Umar Kayam. Karya sastra bukanlah basis kajian utama dalam forum ini, melainkan kerja-kerja budaya sebagai gagasan Kayam. YUK berusaha menafsir cita-cita Umar Kayam dalam mengembangkan potensi sumber daya manusia kreatif, yakni dengan mengembangkan kerja jejaring dan kreativitas. Karya-karya sastra Kayam hanyalah peman- tik dalam kerja jejaring tersebut (Herawati \& Prihandono, 2018: 213).

Eka Wijaya tampak belum siap dan mengatakan bahwa berjejaring perlu energi ekstra. Walaupun pada pertama kali terbit, buku Seribu Kunang-Kunang di Manhattan diluncurkan pada pergelaran acara tahunan Kampung Buku Jogja \#3 bersama Yayasan Umar Kayam pada Jumat 6 Oktober 2017. Di acara ini, menurut Eka Wijaya merupakan agenda darurat dengan persiapan buku hanya 50 eksemplar edisi hard cover. Sebab antrean produksi di percetakan ${ }^{7}$ panjang, buku ter-sebut baru selesai pada akhir Desember dan Pojok Cerpen menyepakati 2018 sebagai tahun terbitan perdananya.

Pojok Cerpen melalui tim kreatif yang juga dikomandani oleh Eka Wijaya menerbitkan buku tersebut dengan dua model, yaitu hard cover dan soft cover. Buku yang dikemas hard cover dicetak 100 eksemplar dengan tujuan sebagai koleksi dibandrol seharga Rp100,000,00. Sebab untuk ukuran ketebalan 120 halaman, buku ini tidak perlu memaksa pengemasan sampul tebal, kecuali dengan tujuan penjualan kepada para kolektor.

Sejumlah 200 eksemplar dikemas dalam bentuk soft cover dengan harga Rp60,000,00. Buku ini kemudian cetak ulang sejumlah 500 eksemplar. Total produksi 800 eksemplar. Penjualan dengan pengemasan sampul konvensional ini ditujukan untuk kalangan pembaca pada umumnya atau pembaca berkarakter kantong tipis. Buku ini tampak lebih tebal untuk ketebalan 120 halaman karena pilihan kertas bookpaper jenis imperial ukuran 72 gsm dari lazimnya buku-buku terbitan Pojok Cerpen yang lain yaitu ukuran 57 gsm. Pilihan ukuran yang juga kecil dalam genggaman berdimensi $12 \times 18 \mathrm{~cm}$. Pojok Cepen memiliki pilihan tiga ukuran yaitu 12 x $18 \mathrm{~cm}$ untuk karya sastra dan 12 x 19 atau 13 x 20 untuk karya pemikiran bergenre esai atau penelitian. Pilihan Pojok Cerpen yang 
lebih kecil dari standar merupakan sebuah pilihan yang berbeda dari penerbit indie yang lain, misalnya Cantrik Pustaka dengan tiga ukuran pilihan yaitu $13 \times 19 \mathrm{~cm}, 14 \times 20$ $\mathrm{cm}$, dan $15,5 \times 23 \mathrm{~cm}$. Begitupun Jalan Baru dengan ukuran $13 \times 20 \mathrm{~cm}$. Pilihan ini oleh Eka Wijaya berdasarkan selera pribadi dan terbilang unik dan nyaman di tangan pembaca.

Ukuran buku ini pula berlaku untuk buku-buku sastra terbitan Pojok Cerpen yang lain seperti Nelayan Itu Berhenti Melaut karya Safar Banggai, Belajar Mencintai Kambing karya Mahfud Ikhwan, Berburu Buaya di Hindia Belanda karya Risda Nur Widia, Nasib Seorang Penebang Kayu \& Kisah Lainnya karya Soesilo Toer, bahkan untuk buku fiksi terjemahan seperti Musyawarah Burung karya Fariduddin Attar. Buku-buku fiksi terbitan Pojok Cerpen yang lain juga memiliki ukuran yang sama.

Pendistribusian dilakukan dengan memprioritaskan penjualan daring. Pojok Cerpen memiliki akun Instagram dengan nama akun penerbit_pocer. Akun ini juga menerima pesanan melalui pesan atau komentar. Dari akun Instagramnya ini terhubung ke beberapa kanal lain yaitu nomor admin yang juga menerima pemesanan, marketplace, situs web, dan Youtube dengan akun Pojok Cerpen. Kanal pada Youtube ini berisikan proses kreatif para penulis Pojok Cerpen yang dikemas dalam bentuk video story. Kanal ini tidak diperuntukkan basis penjualan produk tetapi penjualan konten. Pojok Cerpen juga memiliki Facebook dengan nama Pojok Cerpen dan Twitter dengan nama akun @pojokcerpen yang berfungsi untuk penjualan. Dikarenakan Pojok Cerpen tidak memiliki akun di semua marketplace maka penjualan difokuskan pada situs web masing-masing reseller ${ }^{8}$ Pojok Cerpen. Eka Wijaya mengatakan bahwa Pojok Cerpen sengaja memberi ruang buat para reseller yang basis penjualannya di marketplace. Reseller dengan daya serap tinggi yaitu Berdikari Book, Yogyakarta, Griya Pelangi, Malang, dan Post Santa, Jakarta. Daya serap reseller bisa dipersentase sebanyak $60 \%$ penjualan. Sisanya dari toko buku dan pameran. Sementara untuk situs web Pojok Cerpen sedang melakukan tahapan kontruksi.

Keran distribusi untuk buku Seribu Kunang-Kunang di Manhattan dan buku terbitan Pojok Cerpen lain mengandalkan toko buku konvensional seperti Togamas Yogyakarta, Togamas Bandung, Togamas Malang dan ajang festival tahunan seperti Kampung Buku Jogja dan Mocosik serta festival dwibulanan seperti Patjar Merah dan Tim Three GP yang berkeliling kota secara nasional.

Di antara buku-buku sastra terbitan Pojok Cerpen yang lain, Seribu KunangKunang di Manhattan termasuk kategori buku laku. Eka Wijaya mengaku dibanding buku terbitan di Pojok Cerpen yang lain karya Umar Kayam akan selalu laku di pasar. Buku tersebut sudah mengalami cetak ulang sekali. Setelah pan-demi covid-19 buku tersebut akan dicetak lagi. Namun, tidak dapat serta merta juga disama-kan dengan karya sastra yang lain dari penulis karya sastra pemula seperti Safar Banggai. Sebab dari keduanya memiliki segmentasi pembaca masingmasing. Hal ini juga berlaku dalam industri pasar yang besar jika dihadapkan dengan pasar sastra remaja, seperti sekarang yang tengah beredar di pasaran yaitu novel-novel yang pernah dimuat di Wattpad.

Setelah Seribu Kunang-Kunang di Manhattan terbit, Pojok Cerpen tidak terpikir-kan dengan konsep algoritma media sosial. Keberhasilan Kunang-Kunang di Manhattan di pasar jika diasumsikan karena dampak riwayat produksi dari tahun ke tahun, maka novel Para Priyayi dapat dipastikan mengalami hal yang sama. Pada 2019 buku Saya, Jawa, dan Islam karya Irfan Afifi laku keras di pasa- 
ran dikarenakan tema besar buku ini berbicara tentang Jawa dan Islam. Hal ini berarti jika ditarik dari algoritma pasar tidak menutup kemungkinan Para Priyayi akan me-ngalami respons pasar yang signifikan. Apabila dapat dibandingkan Para Priyayi dengan Gadis Pantai karya Pramoedya Ananta Toer maka Para Priyayi menunjukkan adanya kritik terhadap kehidupan ke-priyayi-an di masyarakat Jawa (David, Aksa, Adji, 2013: 69-80). Demikian juga menurut Hartono bahwa Para Priyayi memot-ret warna lokal Jawa dengan lekat berikut kehidupan dan tradisi masyarakatnya (Hartono, 2015: 396).

Salah satu faktor buku Seribu KunangKunang di Manhattan direspons oleh generasi milenial dan di tengah pasar sastra buku pop penerbit melakukan strategi penjualan yaitu menyertakan sebuah pengantar dari novelis Eka Kurniawan. Eka Kurniawan merupakan peraih penghargaan bergengsi seperti nominasi pada The Man Booker International Prize dan Prince Claus Awards 2018 kategori Sastra/Literatur dari kerajaan Belanda. Pengantar tersebut tidak seluruhnya diletakkan di kover buku, tetapi penggalan pendek pengantar tersebut. Berikut penggalan pengantar bukunya yang dijadikan testimoni:

“Seorang penulis seperti Umar Kayam tak hanya seorang pendongeng yang melaporkan satu keping peristiwa kepada pembacanya, tapi jauh lebih penting adalah seorang teman bicara. Teman ngobrol." Eka Kurniawan

Testimoni yang diberikan Eka Kurniawan menunjukkan bahwa Umar Kayam membu-tuhkan legitimasi untuk menjembatani kepada pembaca zaman sekarang. Penyertaan testimoni ini berawal inisiatif dari gagasan keluarga Umar Kayam. Pojok Cerpen merespons dengan tangan terbuka. Kata pengantar Eka Kurniawan sebagai salah satu ikon penulis kanon sastra kalangan muda berdampak besar bagi pembaca muda. Pojok
Cerpen menyiasati pengantar Eka Kurniawan diletakkan di bela-kang kover buku sebagai testimoni. Strategi politis penjualan ini ditujukan untuk generasi milenial pembaca karya-karya Eka Kurniawan yang luput membaca karya-karya Umar Kayam. Strategi yang dilakukan Pojok Cerpen untuk membangun citra "buku untuk milenial" merupakan serpihan dari gagasan Bourdieu tentang bidang produksi budaya yang menggambarkan artistik atau domain sastra sebagai bidang kekuatan dan perjuang-an. Dengan demikian, karya seni dan juga karya sastra di dalamnya, tidak memiliki nilai yang melekat, tetapi sebuah karya harus diakui dan dikreditkan oleh prinsip yang merujuk pada nilai ekonomi atau prestise yang diraih oleh artis atau pengarang (Bourdieu, 1993: 30); (Abarca, 2017: 18).

\section{Simpulan}

Tidak semua karya yang lahir dari jari jemari Umar Kayam mendapatkan respons yang besar dari pembaca. Untuk itulah Pojok Cerpen hanya optimis ketika mendapatkan mahakarya Umar Kayam seperti Seribu Kunang-Kunang di Manhattan. Untuk karya sastra Umar Kayam yang lain, Pojok Cerpen tidak ingin menggebu-gebu mengambil kebijakan untuk memproduksi ulang. Di samping menerbitkan karya sastra kanon, Pojok Cerpen banyak menerbitkan karya sastra penulis muda.

Kanonitas karya dan kanonitas personal Umar Kayam tidak bisa menjamin kepopuleran Umar Kayam di zaman yang dikuasai generasi milenial dan juga beriring dengan tumbuhnya genre-genre baru sastra Indonesia. Untuk itulah dalam penjualan dibutuhkan strategi untuk masuk ke dalam budaya anak muda. Selain mengatur strategi penjualan seperti promosi di media sosial, membuat kuis, membuat diskon besarbesaran di keran penjualan penerbit, sebuah rumah produksi penerbitan seperti halnya 
Pojok Cerpen, perlu melakukan strategi pembubuhan testimoni/legitimasi dari seorang kanon sastra yang lain dan dianggap relevan dengan situasi dan kondisi pembaca di zamannya.

Di antara keran penjualan Pojok Cerpen di luar perusahaannya seperti para reseller, Togamas, dan festival bisa ditarik inferensi daya serap pembelian reseller sebanyak $60 \%$, sisanya diserap oleh toko buku konvensional seperti Togamas dan festival-festival, termasuk di dalamnya penjualan dari media sosial Pojok Cerpen.

1. Lihat Kekerasan Budaya Pasca 1965: Bagaimana Orde Baru Melegitimasi Anti-Komunisme Melalui Sastra dan Film (2013). Bu$\mathrm{ku}$ ini secara lugas menguak bukti-bukti sejarah terkait kesuksesan Orde Baru mencitrakan sejarah kiri sebagai musuh negara. Upaya yang dila-kukan Wijaya Herlambang, penulis-nya, melakukan pembatasan kajian pada sastra dan film yang kemudian diverifikasi dengan dokumen pribadi dan arsip sejarah.

2. Karakter raksasa yang dimaksud adalah penguasaan pasar, baik secara jumlah produksi maupun persaingan di arena pasar.

3. Pada 2016 akhir penulis melakukan riset di Solusi Distibusi, sebuah perusahaan distributor buku yang berkantor di daerah Deresan di Yogyakarta. Cahyo selaku kepala pemasaran meminta 3.000 atau minimal 2.500 eksemplar kepada Cantrik Pustaka yang saat itu baru berdiri sebagai syarat masuk distribusi. Solusi Distribusi berhak memberikan pinalti berupa uang kepada penerbit yang dalam waktu satu bulan tidak menyerahkan bukti terbit untuk didistribusikan minimal 3 judul.

4. Penulis pernah bekerja di perusahaan distributor Lumbung Kita Yogyakarta pada 2017. Setiap naskah yang akan diterbitkan oleh penerbit wajib menye-rahkan naskah dalam bentuk dummy (cetak coba) untuk diseleksi baik konten isi maupun visual ilustrasi. Dalam kasus buku Kill The Radio (Mata Angin, 2017) terpaksa tidak lolos seleksi, P2B Gramedia meminta untuk mengubah ilustrasi buku yang berbau unsur komunisme. Dalam konfirmasi yang dilakukan distri-butor kepada P2B Gramedia, pihak toko tidak ingin ikut terlibat dalam pendistribusian produk yang dapat menimbulkan reaksi massa. Kasus ini ditandai kemu-dian dengan Ormas yang melakukan razia atas buku-buku kiri di beberapa kota.

5. Lihat http://ensiklopedia.kemdikbud.go.id/sastra/ artikel/Seribu_Kunang-Kunang_di_Manhattan. Sunoto Surodibroto menulis esai dari wawancaranya dengan Umar Kayam yang berjudul "Proses Penulisan Umar Kayam" yang dimuat di Berita Buana 9 Juni 1985.

6. Wawancara dengan Eka Wijaya, CEO Pojok Cerpen, pada 28 April 2020.

7. Penerbit indie rata-rata tidak memiliki mesin cetak sendiri. Pojok Cerpen sebagian besar bukunya dicetak di Utama Offset, sebuah percetakan yang berlokasi Yogyakarta.

8. Istilah reseller mengacu kepada toko buku berbasis daring. Walaupun dalam perkembangannya reseller ini mengem- bangkan dirinya menjadi toko buku luring seperti Berdikari Book, Yogyakarta dan Post Santa, Jakarta. Namun, tidak semua reseller berbasis toko buku daring bisa dikunjungi toko daringnya misalnya Stan Buku dan Serba Sastra.

\section{Daftar Pustaka}

Abarca, Jesús Eduardo Oliva. 2017. "Factors of Positioning and Accreditation of Cultural Agents in a Local Field of Cultural Production." Rupkatha Journal on Interdisciplinary Studies in Humanities 9(3):16-26. https:// doi.org/10.21659/rupkatha.v 9n3.04

Anwar, Saeful. 2015. "Produksi Simbol Dalam Sampul Buku Sastra Terbitan Gramedia." Jurnal POETIKA 3(2). https:// doi.org/10.22146/poetika.104 28

Bourdieu, Pierre. 1993. The Field of Cultural Production. Essays on Art and Literature. New York: Columbia University Press.

Budiman, Irfan. 1999. "Seribu KunangKunang Di Langit Yang Gelap." Koran Tempo. Retrieved April 12, 2021 (https://majalah.tempo.co/read/buk u/98360/seribu-kunang-kunang-dilangit-yang-gelap).

Dewanto, Nirwan. 2005. Umar Kayam Luar Dalam: 30 April 1932-16 Maret 2002. Yogyakarta: Yayasan Seribu KunangKunang dan Pinus.

Goldmann, Lucien. 1980. Essays on Method in the Sociology of Literature. St Louis: Telos Press.Ltd. https:// doi.org/10.3817/0980045150

Hartono. 2015. "Warna Lokal Jawa dalam Novel Indonesia Periode 1980-1995." Litera 14(2):392-403. doi: 
https:/ / doi.org/10.21831/ltr.v14i2.72 12

Herawati, F. Anita dan Bambang K. Prihandono. 2018. "Peran Jejaring Sosial dalam Pembangunan Komunitas Kreatif." hlm. 184-219 in Inovasi, Komunikasi, Kolaborasi: Strategi dan Kajian Membangun Masyarakat Kreatif di Era Digital, edited by B. P. Pratama. Yogyakarta: Fakultas Ilmu Sosial dan Ilmu Politik Universitas Atma Jaya Yogyakarta.

Hopf, Christel. 2004. "Qualitative Interviews: An Overview." Pp. 203-9 in A Companion to Qualitative Research, edited by E. von K. and I. S. Uwe Flick. London: Sage Publications.

Kasijanto, Kasijanto. 2008. "Media dan Monopoli Dagang Percetakan dan Penerbitan di Indonesia pada Masa VOC." Wacana, Journal of the Humanities of Indonesia 10(2). https:// doi.org/10.17510/wjhi.v10i2.1 98

Liliani, Else. 2011. Sistem Produksi dan Distribusi Novel Anak Islami di Indonesia Tahun 2000-An. Yogyakarta.

Linda, Lisma. 2019. “Kekuasaan Dan Kepentingan Internal Lembaga: Kajian Arena Produksi Kultural Bourdieu (Studi Kasus Penerbit Bandar Publishing di Kota Banda Aceh)." Aceh Anthropological Journal 3(2):15777.

https:/ / doi.org/10.29103/aaj.v3i2.277 9

Murti, Ghanesya Hari. 2016. "Membongkar Legitimasi Sastra Kanon Dan Populer: Deterritorialisasi
Karya D." Pp. 278-85 in Sastra, Budaya, dan Perubahan Sosial, edited by A. Setijowati. Surabaya: Lembaga Penelitian dan Pengabdian kepada Masyarakat Universitas Kristen Petra.

Rahmanto, B. 2004. Umar Kayam: Karya dan Dunianya. Jakarta: Grasindo.

Razif. 2005. Bacaan Liar Budaya dan Politik Zaman Pergerakan. Edi Cahyono's Experience.

Salam, Aprinus, and Saeful Anwar. 2015. "Strategi dan Legitimasi Komunitas Sastra di Yogyakarta: Kajian Sosiologi Sastra Pierre Bourdieu." Widyaparwa 43(1):25-37. doi: https://doi.org/10.26499/wdprw.v43 i1.103.

Schwetter, Holger. 2019. "From Record Contract to Artrepreneur? Musicians' Self-Management and the Changing Illusio in the Music Market." Kritika Kultura (32):184-207. https:/ / doi.org/10.13185/KK2019.032 10

Setiadi, David, Yati Aksa, dan M. Adji. 2013. “Konsep Ke-Priyayi-an Yang Terefleksi dalam Novel Para Priyayi Karya Umar Kayam dan Gadis Pantai Karya Pramoedya Ananta Toer." Jurnal Widyaparwa 41(1):69-80. doi: https:// doi.org/10.26499/wdprw.v41 i1.67.

Situmorang, Saut. 2007. "Politik Kanon Sastra." 15.

Sudibyo, Sudibyo. 2015. “Analisis Ceerpen Parta Krama Karya Umar Kayam Menurut Repertoire Iser." Diksi 16(6). https:// doi.org/10.21831/diksi.v16i6. 
7061

Sugono, Dendy (ed). 2003. Ensiklopedi Sastra Indonesia Modern. edited by D. Sugono. Jakarta: Pusat Bahasa.

Sulton, Agus. 2015. "Sastra 'Bacaan Liar' Harapan Menuju Kemerdekaan." Jurnal Pendidikan Bahasa Dan Sastra 15(2).

https:/ / doi.org/10.17509/bs_jpbsp.v1 5i2.1242

Sumarno. 2015. "Kanonisasi Sastra dan NIlai-Nilai Sosial Budaya Bangsa." Edukasi Lingua Sastra 13(1):20-29.
Suwondo, Tirto. 1997. Karya Sastra di Luar Penerbitan Balai Pustaka. Jakarta: Pusat Pembinaan dan Pengembangan Bahasa.

Trianton, Teguh. 2019. Disrupsi dan Kanonisasi Sastra. Banyumas. https:// doi.org/10.31227/osf.io/97qv $\mathrm{m}$

Zamzuri, Ahmad. 2014. "Modal-Modal Majalah Pagagan: Tinjauan Sosiologi Pierre Bourdieu." Widyaparwa 42(2):165-76.

https:// doi.org/10.26499/wdprw.v42 i2. 95 